\title{
Occurrence of Acanthamoeba species in the Damanhour Drinking Water Treatment Plant, Behera Governorate (Egypt)
}

This article was published in the following Dove Press journal:

Reports in Parasitology

22 July 2015

Number of times this article has been viewed

\author{
Ahmad Z Al-Herrawy' \\ Mohamed G Heshmat ${ }^{2}$ \\ Shaban H Abu Kabsha ${ }^{3}$ \\ Mahmoud A Gad' \\ Wael M Lotfy ${ }^{2}$ \\ 'Water Pollution Research \\ Department, National Research \\ Centre, Cairo, Egypt; ${ }^{2}$ Parasitology \\ Department, Medical Research \\ Institute, Alexandria University, \\ Alexandria, Egypt; ${ }^{3}$ Behera Water and \\ Drainage Company, Damanhour, Egypt
}

Correspondence: Wael M Lotfy Parasitology Department, Medical Research Institute, Alexandria University, I65 El-Horreya Avenue,

Alexandria, Egypt

$\mathrm{Tel}+201008154959$

Email waelotfy@alexu.edu.eg

\begin{abstract}
Members of the genus Acanthamoeba are common free-living amoebae that may be pathogenic to humans. The aim of the present work was to evaluate the presence of Acanthamoeba species in the Damanhour Drinking Water Treatment Plant (DWTP) before and after conventional drinking water treatment. Water samples were filtered through nitrocellulose membranes of $0.45 \mu \mathrm{m}$ pore size, cultured on nonnutrient agar plates seeded with Escherichia coli, and incubated at $37^{\circ} \mathrm{C}$. The obtained amoebae, which proved to be morphologically consistent with Acanthamoeba spp., were confirmed by polymerase chain reaction (PCR). The confirmed isolates of Acanthamoeba were morphologically identified to the species level, based on assessment of the size and shape of the endo- and ectocysts and the mean number of pores per cyst. The obtained results showed that members of the genus Acanthamoeba were isolated from 33.3\% and $16.7 \%$ of inlet and outlet samples, respectively. Six different species of Acanthamoeba were morphologically identified. Species morphologically identified as Acanthamoeba castellanii, Acanthamoeba culbertsoni, and Acanthamoeba polyphaga were isolated from the "finished" water of DWTP. Such species may be pathogenic to humans. In conclusion, the conventional drinking water treatment steps did not remove all the detected species of Acanthamoeba in the inlet water, and about half of them could escape to completely treated and finished water. These species may cause human infections.
\end{abstract}

Keywords: free-living, amoebae, identification, morphology, PCR

\section{Introduction}

Acanthamoeba spp. are free-living amoebae that are common in natural environments. They can cause serious human infections, such as granulomatous amebic encephalitis and amoebic keratitis. However, not all species or strains are pathogenic to humans. ${ }^{1}$ Acanthamoeba castellanii, Acanthamoeba culbertsoni, Acanthamoeba hatchetti, Acanthamoeba healyi, Acanthamoeba polyphaga, Acanthamoeba rhysodes, Acanthamoeba astronyxis, and Acanthamoeba divionensis have all been implicated in human infections. ${ }^{2}$ Acanthamoeba spp. can be found in soil, air, and water. They have the ability to survive in diverse aquatic environments and have been isolated from public water supplies, swimming pools, bottled water, seawater, pond water, stagnant water, freshwater lakes, salt water lakes, river water, distilled water bottles, ventilation ducts, the water-air interface, air-conditioning units, sewage, compost, sediments, soil, beaches, vegetables, air, surgical instruments, and contact lenses, indicating the ubiquitous nature of these organisms. ${ }^{2-8}$ In addition, Acanthamoebae have been recovered from hospitals, dialysis units, eye wash stations, human nasal cavities, pharyngeal swabs, lungs tissues, skin lesions, corneal biopsies, cerebrospinal fluid (CSF), and brain necropsies. ${ }^{9}$ 
Acanthamoeba spp. have two stages during their life cycle: a vegetative or trophozoite stage $(8-40 \mu \mathrm{m})$ and a dormant cyst stage $(8-29 \mu \mathrm{m})$. Trophozoite morphology is characterized by the presence of a single nucleus and fine acanthopodia projecting outward from the surface of the body. The acanthopodia allow adhesion to surfaces, cellular movements, and capture of pray. Trophozoite forms feed, grow, and reproduce by binary fission. ${ }^{10}$ Acanthamoeba trophozoites cannot survive a long time in an adverse environmental condition (for example, lack of food, extremes in temperature or $\mathrm{pH}$, or hypo- or hyperosmolarity) and differentiate into uninucleate cysts with a double-walled structure (endo- and ectocyst). The cyst forms are nonfeeding, nongrowing, and nonreproducing forms. The cyst form is a resistant form possessing pores, which are used to monitor environmental changes. The cyst form is protected from desiccation, starvation, and a variety of chemical and physical agents. ${ }^{11,12}$ Cysts have been known to survive in vitro for 20 years or more. With the return of optimal conditions for growth, especially food, cysts germinate to give rise to trophic forms..$^{13}$ Acanthamoeba cysts have been shown to remain viable after treatment with $100 \mathrm{mg} / \mathrm{L}$ chlorine (free and combined) for 10 minutes; they were shown to survive as well at $80^{\circ} \mathrm{C}$, implying that conventional hyperdisinfection may be insufficient for long-term control of Acanthamoeba..$^{13}$

Acanthamoeba spp., like other free-living amoebae, feed on microorganisms present on wet surfaces, in diverse environments, ${ }^{14}$ and even at the air-water interface. ${ }^{15}$ Based on morphological criteria, more than 24 species of Acanthamoeba have been identified, which can be assigned to three groups. ${ }^{16,17}$ The spiny structures or acanthopodia that arise from the surface of Acanthamoeba trophozoites may be used to capture food particles, which are usually bacteria, ${ }^{18}$ algae, and yeast. ${ }^{19}$

Acanthamoeba spp. can serve as hosts for a large number of pathogenic bacteria, including Legionella spp., Vibrio cholerae, Burkholderia cepacia, Listeria monocytogenes, Escherichia coli O157, Mycobacterium bovis, and Mycobacterium avium..$^{20,21}$ Approximately, 20\%-24\% of clinical and environmental isolates of Acanthamoeba harbor intracellular bacteria. ${ }^{22}$ Moreover, Acanthamoebae can harbor echovirus. ${ }^{1}$ Recently, a mimivirus was discovered in A. polyphaga. ${ }^{23} \mathrm{In}$ addition, it is known that coxsackie viruses and adenoviruses can infect Acanthamoeba. ${ }^{24}$ The intracellular localizations of these microorganisms protect them from adverse conditions and allow the bacteria to evade host defenses, to resist antibiotic actions, and to increase their virulence. ${ }^{25}$ Also, biofilms formed in aqueous environments (intravenous catheters, contact lens, sclera buckles, dental units, etc) are known to be a reservoir for a large number of microorganisms. These play an important role in the pathogenesis of Acanthamoeba, particularly, in keratitis infections, and provide the parasite with an attractive niche and an abundant nutrient. ${ }^{14}$

In Egypt, scarce data are available concerning species of Acanthamoeba in freshwater and tap water. So, the aim of the present work was to identify Acanthamoeba spp. isolated from a drinking water treatment facility in Damanhour city, in the Behera Governorate, Egypt.

\section{Materials and methods Samples}

Water samples (2 L volume, each) were collected from the Damanhour Drinking Water Treatment Plant (DWTP), Damanhour city, Behera Governorate, Egypt (Figure 1). The inlet of Damanhour DWTP receives its water from the Eastern Khandak Canal, which is a branch of the ElRayah El-Behery Canal. The treatment system of this station begins with coarse sieving of the raw water, followed by prechlorination, clarification, slow sand filtration, and finally postchlorination of the treated water in storage tanks. Before pumping to the distribution system, another booster dose of chlorine is added to the drinking water in order to reach the consumer in a safe mode, with about $0.5 \mathrm{ppm}$ residual chlorine. The Damanhour DWTP produces 1,200 cubic liters of drinking water per second and serves about 320,000 persons. For our study, two types of water samples were collected: raw surface water (intake of the Damanhour DWTP) and "finished" water (completely treated and chlorinated, from the outlet of the Damanhour DWTP). Two water samples were collected monthly - one from each water type - during the 1-year period from August 2010 to July 2011.

\section{Collection of Acanthamoebae}

The collected water samples were separately filtered through nitrocellulose membrane filters $(0.45 \mu \mathrm{m}$ pore size and $47 \mathrm{~mm}$ diameter) using a stainless steel vacuum filter holder (Sartorius SM, Göttingen, Germany). Then, each membrane was inverted face-to-face on the surface of a nonnutrient agar plate seeded with living E. coli bacteria and incubated at $37^{\circ} \mathrm{C}$ for 1 week, with daily microscopic examination using the inverted microscope. ${ }^{1,4}$ The grown Acanthamoeba trophozoites were characterized from other free-living amoebae by their pointed pseudopodia (acanthopodia), while the cyst forms were easily identified by their double cyst wall and conventionally stellate shape. ${ }^{26}$ 


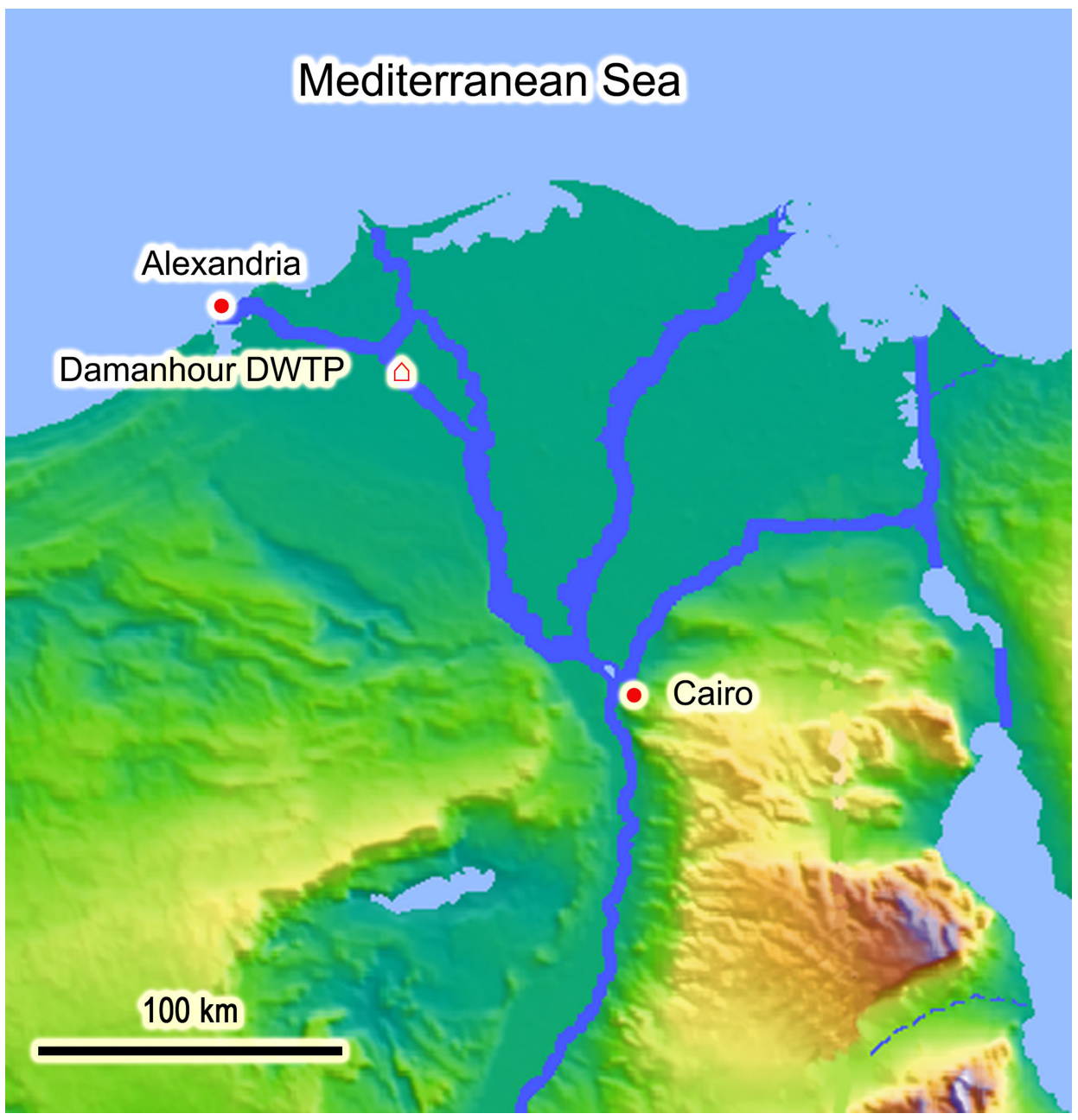

Figure I Location of the Damanhour DWTP.

Abbreviation: DWTP, Drinking Water Treatment Plant.

\section{Molecular characterization}

The morphologically suspected isolates of Acanthamoeba were subjected to molecular characterization. Cyst walls of these isolates were perforated by three consecutive applications of freezing and thawing in liquid nitrogen, followed by incubation in a water bath at $100^{\circ} \mathrm{C}$ for 10 minutes. DNA was then extracted using phenol/ chloroform/isoamyl alcohol, as described by Winnepenninckx et $\mathrm{al}^{27}$ and modified by Abdel-Hamid et al. ${ }^{28}$ For the detection of Acanthamoeba spp., a primer pair, namely AcantF900 (5'-CCC AGA TCG TTT ACC GTG AA-3') and AcantR1100 (5'-TAA ATA TTA ATG CCC CCA ACT ATC C- $3^{\prime}$ ), were used to amplify a $18 \mathrm{~S}$ ribosomal (r)RNA gene fragment of approximately $180 \mathrm{bp}$ (differing by a few bases, depending on the species). ${ }^{29}$ Amplification of DNA was performed using Maxima ${ }^{\text {TM }}$ Hot Start Green PCR Master Mix (Thermo Fisher Scientific Inc, Waltham, MA, USA) according to the manufacturer manual. The polymerase chain reaction $(\mathrm{PCR})$ reaction mixture used per sample consisted of: $25 \mu \mathrm{L}$ Maxima Hot Start Green PCR Master Mix (2×), $3 \mu \mathrm{L}$ template DNA, $1 \mu \mathrm{L}$ of each primer, and $25 \mu \mathrm{L}$ diethylpyrocarbonate (DEPC)-treated water. A hotstart procedure for Acanthamoeba spp. was used, with an initial denaturation at $95^{\circ} \mathrm{C}$ for 4 minutes, followed by 35 cycles of denaturation at $94^{\circ} \mathrm{C}$ for 30 seconds, primer annealing at $55^{\circ} \mathrm{C}$ for 30 seconds, and extension at $72^{\circ} \mathrm{C}$ for 30 seconds. A final extension step was performed at $72^{\circ} \mathrm{C}$ for 10 minutes. The DNA was visualized using ethidium bromide.

\section{Morphological speciation}

The isolates of Acanthamoeba confirmed by PCR technique were morphologically identified to the species level, based on assessment of the size and shape of the endo- and ectocysts, and the mean number of pores per cyst, using the method described by Pussard and Pons. ${ }^{16}$ 


\section{Results}

\section{Prevalence of Acanthamoeba} species in the Damanhour DWTP

Examination of 48 water samples collected from Damanhour DWTP revealed the presence of different Acanthamoeba species in $12(25 \%)$ of them. About $33.3 \%$ of the examined inlet water samples were found to contain Acanthamoeba species, while only $16.7 \%$ of the examined outlet drinking water samples had Acanthamoeba species (Table 1).

\section{Seasonal variation of Acanthamoeba species in the Damanhour DWTP}

Concerning the seasonal variation of Acanthamoeba isolated from the Damanhour DWTP, it was observed that they were found in the inlet water samples in a same percentage $(33.3 \%)$ in all seasons of the year. On the other hand, the occurrence of Acanthamoeba spp. in the outlet drinking water samples reached $33.3 \%$ in each of spring and summer seasons, while they were completely absent in the outlet samples collected in both winter and autumn (Table 2).

\section{Elimination of Acanthamoeba species during the drinking water treatment process}

It was found that the number of Acanthamoeba-positive samples in the finished (outlet) water was lower than that in the inlet samples, indicating that the efficiency of all treatment processes for the elimination of Acanthamoeba species from the inlet water in the Damanhour DWTP reached 50\% (Table 3).

\section{Confirmation of the morphologically identified isolates to the genus level by PCR}

When the microscopically-positive water samples for Acanthamoeba spp. were subjected to DNA extraction, amplification, and agarose gel electrophoresis, genus-specific bands (for Acanthamoeba spp.) were visualized by ultraviolet

Table I Prevalence of Acanthamoeba in Damanhour DWTP

\begin{tabular}{llll}
\hline $\begin{array}{l}\text { Type of } \\
\text { water }\end{array}$ & $\begin{array}{l}\text { Total } \\
\text { examined } \\
\text { samples (N) }\end{array}$ & \multicolumn{2}{l}{$\begin{array}{l}\text { Acanthamoeba +ve } \\
\text { samples }\end{array}$} \\
\cline { 3 - 4 } & 24 & $\mathbf{n}$ & $\%$ \\
\hline Inlet & 24 & 8 & 33.3 \\
Outlet & 48 & 4 & 16.7 \\
Total & I & 12 & 25 \\
\hline
\end{tabular}

Abbreviations: +ve, positive; DWTP, Drinking Water Treatment Plant.
Table 2 Seasonal variation of Acanthamoeba in Damanhour DWTP

\begin{tabular}{llllll}
\hline Season & \multicolumn{3}{l}{ Acanthamoeba spp. } \\
\cline { 2 - 3 } & Inlet samples & & Outlet samples & \\
\cline { 2 - 3 } & +ve/examined & $\%$ & & +velexamined & $\%$ \\
\hline Winter & $2 / 6$ & 33.3 & & $0 / 6$ & 0.0 \\
Spring & $2 / 6$ & 33.3 & & $2 / 6$ & 33.3 \\
Summer & $2 / 6$ & 33.3 & & $2 / 6$ & 33.3 \\
Autumn & $2 / 6$ & 33.3 & & $0 / 6$ & 0.0 \\
\hline
\end{tabular}

Abbreviations: +ve, positive; DWTP, Drinking Water Treatment Plant.

(UV) transilluminator. It was found that all the microscopically Acanthamoeba-positive samples gave specific bands at about 180 bp (Figure 2).

\section{Morphological identification of Acanthamoeba spp. confirmed by PCR}

The confirmed Acanthamoeba isolates were morphologically identified, revealing the presence of six different species on the basis of cyst morphology (Figure 3). The identified six Acanthamoeba spp. were A. astronyxis, Acanthamoeba royreba, Acanthamoeba comandoni, A. culbertsoni, Acanthamoeba quina, and A. polyphaga. Morphological criteria of the isolated six species of Acanthamoeba spp. are presented in Table 4.

\section{Discussion}

During the present study, species of the genus Acanthamoeba were isolated from $33.3 \%$ of inlet water samples of the Damanhour DWTP. Acanthamoeba spp. were detected at higher percentages $(66.7 \%, 40 \%$, and $43.1 \%$, respectively) in the examined Nile water of Egypt by Al-Herrawy, ${ }^{30}$ Hamadto et al, ${ }^{31}$ and Hilali et al. ${ }^{32}$ Also, during the present work, Acanthamoeba spp. were isolated from $16.7 \%$ of the examined finished water samples of the Damanhour DWTP. In other studies in Egypt, Al-Herrawy et al recorded a higher occurrence $(58.6 \%),{ }^{33}$ while Hamadto et al recorded a lower occurrence (4\%). ${ }^{31}$ In the United Kingdom, Acanthamoeba spp. were isolated from $26.9 \%$ of tap water samples by Kilvington et al. ${ }^{34}$ The difference in detection rates of free-living amoebae in different countries and localities may be influenced by geographical conditions and raw water sources. ${ }^{35-37}$

Table 3 Elimination of Acanthamoeba during drinking water treatment process

\begin{tabular}{ll}
\hline Water type & $\begin{array}{l}\text { Number of Acanthamoeba } \\
\text { +ve samples }\end{array}$ \\
\hline Inlet & 8 \\
Outlet & 4 \\
Elimination \% (-ve outlet/+ve inlet) & $50 \%$ \\
\hline
\end{tabular}

Abbreviations: -ve, negative; +ve, positive. 


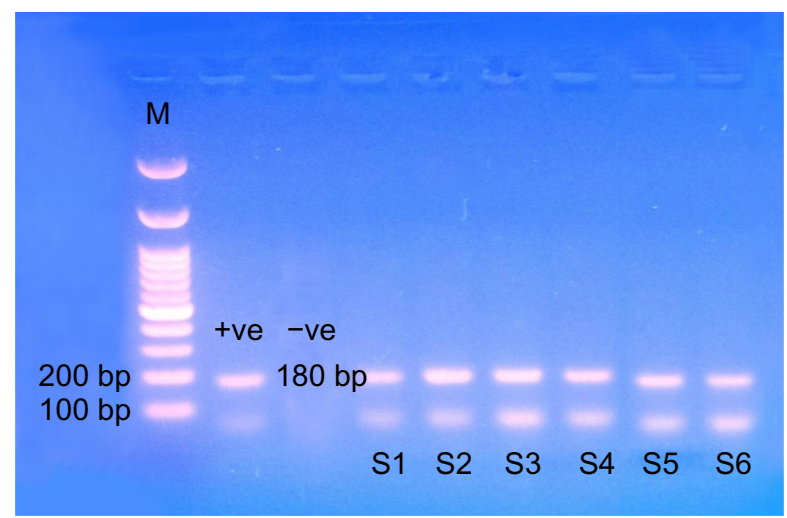

Figure 2 Ethidium bromide-stained $2 \%$ agarose gel showing PCR-amplified product of extracted DNA from Acanthamoeba.

Notes: Lane I shows the marker ( 100 plus DNA ladder); lane 2 shows the positive control; lane 3 shows the negative control; and lanes 4-9 show samples of the morphologically identified six species of Acanthamoeba, labeled SI-S6.

Abbreviations: -ve, negative; +ve, positive; M, marker; PCR, polymerase chain reaction.

The results of the present study showed that the percentage of Acanthamoeba-positive samples in the inlet water of the DWTP were the same in all seasons of the year $(33.3 \%)$. However, in the outlet drinking water, the percentage of positive samples reached $33.3 \%$ in spring and summer, while they were $0 \%$ in both winter and autumn. Several workers in different countries reported seasonal variations in the distribution of Acanthamoeba in freshwater samples, with the highest percentage either in autumn ${ }^{38-40}$ or in summer. ${ }^{37,41,42}$

During the present study, a simple PCR technique was applied, using genus-specific primers, to confirm the results obtained by morphological identification of the isolated Acanthamoeba, but PCR confirmation at the species level is still needed. PCR has been found to be a more sensitive diagnostic test than culture..$^{43}$

Identification of some pronounced Acanthamoeba spp. can be accomplished by the morphological characteristics. In fact, more than 24 species of Acanthamoeba have been identified based on morphological criteria. ${ }^{16,17}$ Members of the genus Acanthamoeba are divided into three morphological groups according to the cyst size and other morphological features. Group 1 consists of Acanthamoeba spp. with relatively large cysts, distinctly stellate endocysts, and smooth spherical ectocysts. Group 2 and group 3 Acanthamoeba spp. have smaller cysts (less than $18 \mu \mathrm{m}$ in diameter). Species in group 2 have polygonal to stellate endocysts, with irregular or wrinkled ectocysts, while the cysts of group 3 species have rounded or slightly angular endocysts, with thinner and smooth or slightly wrinkled ectocysts. ${ }^{16,17}$ According to the results of the present work, six different species of Acanthamoeba were morphologically identified. Morphologically, two species (A. astronyxis and A. comandoni) of the isolated Acanthamoeba spp. belonged to group 1, two species (A. polyphaga and A. quina) belonged to group 2, and two species (A. culbertsoni and A. royreba) belonged to group 3 .

Some Acanthamoeba spp. can cause human infections, such as A. castellanii, A. culbertsoni, A. hatchetti, A. healyi, A. polyphaga, A. rhysodes, A. astronyxis, and A. divionensis. ${ }^{1,2}$ During the present study, three species morphologically identified as A. castellanii, A. culbertsoni, and $A$. polyphaga were isolated from the finished water of the DWTP. Such species may be pathogenic to humans.
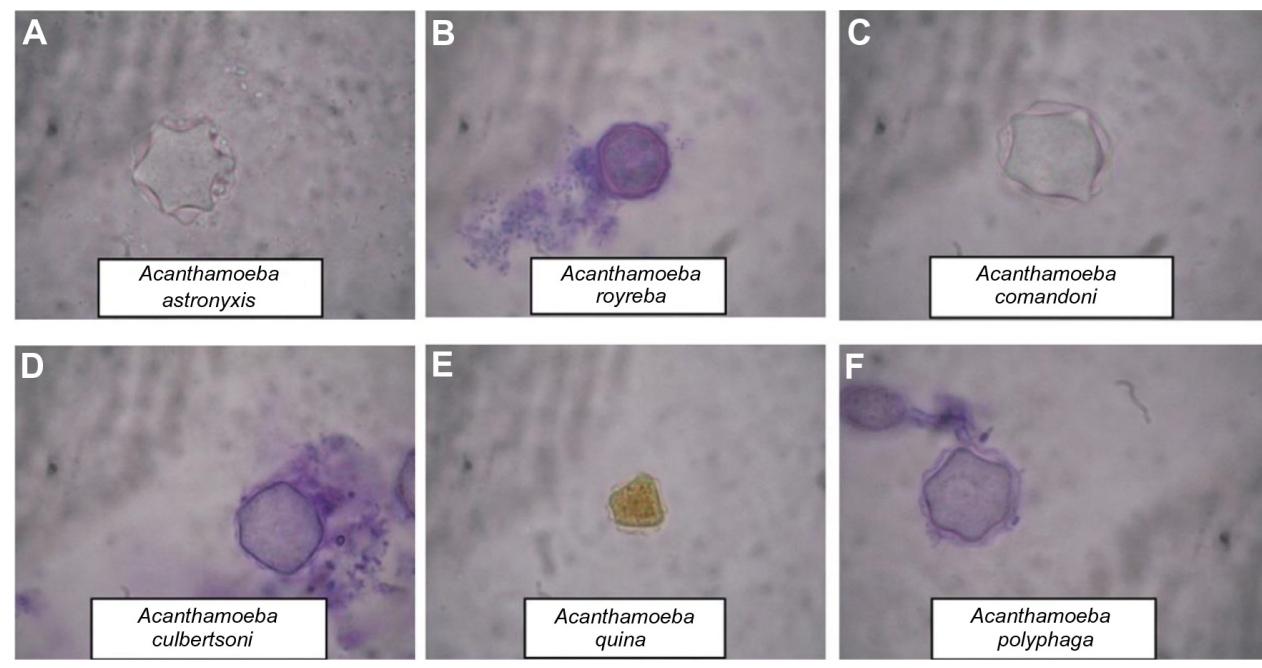

Figure 3 Cyst morphology of isolated Acanthamoeba spp.

Notes: (A and C) were unstained; (B), (D), and (F) were stained with Field's stain; and (E) was stained with Lugol's iodine stain. 
Table 4 Morphological characters of isolated Acanthamoeba cysts of the different species

\begin{tabular}{|c|c|c|c|c|}
\hline \multirow[t]{2}{*}{ Acanthamoeba isolates } & \multicolumn{4}{|l|}{ Cyst morphology } \\
\hline & Cyst diameter $(\mu \mathrm{m})$ & Endocyst & Number of pores & Ectocyst \\
\hline Acanthamoeba astronyxis & 19-22 $\mu \mathrm{m}$ & Stellate & 5 & Very delicate, not wrinkled \\
\hline Acanthamoeba royreba & $14-16 \mu \mathrm{m}$ & Nearly round & $12-14$ & Slightly wrinkled \\
\hline Acanthamoeba comandoni & $20-25 \mu \mathrm{m}$ & Stellate & $6-7$ & Delicate, not wrinkled \\
\hline Acanthamoeba culbertsoni & $13.5-15 \mu \mathrm{m}$ & $\begin{array}{l}\text { Not predominantly stellate, } \\
\text { nearly rounded with slight angles }\end{array}$ & $5-6$ & Little, slightly wrinkled \\
\hline Acanthamoeba quina & $12-13 \mu \mathrm{m}$ & Firmly prominent & $4-5$ & Noticeably wrinkled \\
\hline Acanthamoeba polyphaga & $12-15 \mu \mathrm{m}$ & Nearly round with slight angles & $5-6$ & Closely encircling endocyst \\
\hline
\end{tabular}

\section{Conclusion}

Acanthamoeba spp. were still present in the drinking water produced by the Damanhour DWTP, although they had been exposed to all steps of conventional drinking water treatment. This may denote a public health hazard to the users.

\section{Acknowledgment}

The authors are deeply indebted to the authority of the Behera Water and Drainage Company for facilitating the sample collection.

\section{Disclosure}

The authors report no conflicts of interest in this work.

\section{References}

1. Schuster FL, Visvesvara GS. Opportunistic amoebae: challenges in prophylaxis and treatment. Drug Resist Updat. 2004;7(1):41-51.

2. Szénási Z, Endo T, Yagita K, Nagy E. Isolation, identification and increasing importance of 'free-living' amoebae causing human disease. J Med Microbiol. 1998;47(1):5-16.

3. Rivera F, Roy-Ocotla G, Rosas I, Ramirez E, Bonilla P, Lares F. Amoebae isolated from the atmosphere of Mexico City and environs. Environ Res. 1987;42(1):149-154.

4. Eaton AD, Clesceri LS, Rice EW, Greenberg AE, Franson MAH, editors. Standard Methods for the Examination of Water and Wastewater: Centennial Edition. 21st ed. Washington, DC: American Public Health Association; 2005.

5. Lass A, Szostakowska B, Idzińska A, Chomicz L. The first genotype determination of Acanthamoeba potential threat to human health, isolated from natural water reservoirs in Poland. Parasitol Res. 2014;113(7):2693-2699.

6. Todd CD, Reyes-Batlle M, Martín-Navarro CM, et al. Isolation and genotyping of acanthamoeba strains from soil sources from Jamaica, west indies. $J$ Eukaryot Microbiol. 2015;62(3):416-421.

7. Cruz AR, Rivera WL. Genotype analysis of Acanthamoeba isolated from human nasal swabs in the Philippines. Asian Pac J Trop Med. 2014;7S1:S74-S78.

8. Al-Herrawy A, Bahgat M, Mohammed AE, Ashour A, Hikal W. Acanthamoeba species in Swimming Pools of Cairo, Egypt. Iran $J$ Parasitol. 2014;9(2):194-201.

9. Shoff ME, Rogerson A, Kessler K, Schatz S, Seal DV. Prevalence of Acanthamoeba and other naked amoebae in South Florida domestic water. J Water Health. 2008;6(1):99-104.

10. Khan NA. Acanthamoeba: biology and increasing importance in human health. FEMS Microbiol Rev. 2006;30(4):564-595.
11. Aksozek A, McClellan K, Howard K, Niederkorn JY, Alizadeh H. Resistance of Acanthamoeba castellanii cysts to physical, chemical, and radiological conditions. J Parasitol. 2002;88(3):621-623.

12. MacLean RC, Hafez N, Tripathi S, Childress CG, Ghatak NR, MarcianoCabral F. Identification of Acanthamoeba sp. in paraffin-embedded CNS tissue from an HIV+ individual by PCR. Diagn Microbiol Infect Dis. 2007;57(3):289-294.

13. Mazur T, Hadaś E, Iwanicka I. The duration of the cyst stage and the viability and virulence of Acanthamoeba isolates. Trop Med Parasitol. 1995;46(2):106-108.

14. Brown MR, Barker J. Unexplored reservoirs of pathogenic bacteria: protozoa and biofilms. Trends Microbiol. 1999;7(1):46-50.

15. Preston TM, Richards H, Wotton RS. Locomotion and feeding of Acanthamoeba at the water-air interface of ponds. FEMS Microbiol Lett. 2001;194(2):143-147.

16. Pussard M, Pons R. Morphologie de la paroi kystique et taxonomie du genre Acanthamoeba (Protozoa, Amoebida). [Morphology of the cyst wall and taxonomy of the genus Acanthamoeba (Protozoa, Amoebida)]. Protistologica. 1977;13(4):557-598. French.

17. Page FC. A New Key to Freshwater and Soil Gymnamoebae: With Instructions for Culture. Ambleside: Freshwater Biological Association; 1988.

18. Weekers PH, Bodelier PL, Wijen JP, Vogels GD. Effects of grazing by the free-living soil amoebae Acanthamoeba castellanii, Acanthamoeba polyphaga, and Hartmannella vermiformis on various bacteria. Appl Environ Microbiol. 1993;59(7):2317-2319.

19. Allen PG, Dawidowicz EA. Phagocytosis in Acanthamoeba: I. A mannose receptor is responsible for the binding and phagocytosis of yeast. J Cell Physiol. 1990;145(3):508-513.

20. Thom S, Warhurst D, Drasar BS. Association of Vibrio cholerae with fresh water amoebae. J Med Microbiol. 1992;36(5):303-306.

21. Ben Salah I, Drancourt M. Surviving within the amoebal exocyst: the Mycobacterium avium complex paradigm. BMC Microbiol. 2010;10:99.

22. Fritsche TR, Horn M, Wagner M, Herwig RP, Schleifer KH, Gautom RK. Phylogenetic diversity among geographically dispersed Chlamydiales endosymbionts recovered from clinical and environmental isolates of Acanthamoeba spp. Appl Environ Microbiol. 2000;66(6):2613-2619.

23. Suzan-Monti M, La Scola B, Barrassi L, Espinosa L, Raoult D. Ultrastructural characterization of the giant volcano-like virus factory of Acanthamoeba polyphaga Mimivirus. PLoS One. 2007;2(3):e328.

24. Lorenzo-Morales J, Coronado-Alvarez N, Martínez-Carretero E, Maciver SK, Valladares B. Detection of four adenovirus serotypes within water-isolated strains of Acanthamoeba in the Canary Islands, Spain. Am J Trop Med Hyg. 2007;77(4):753-756.

25. Marciano-Cabral F, Cabral G. Acanthamoeba spp. as agents of disease in humans. Clin Microbiol Rev. 2003;16(2):273-307.

26. Page FC. Taxonomic criteria for limax amoebae, with descriptions of 3 new species of Hartmannella and 3 of Vahlkampfia. J Protozool. 1967;14(3):499-521. 
27. Winnepenninckx B, Backeljau T, De Wachter R. Extraction of high molecular weight DNA from molluscs. Trends Genet. 1993; 9(12):407.

28. Abdel-Hamid AHZ, de Molfetta JB, Fernandez V, Rodrigues V. Genetic variation between susceptible and non-susceptible snails to Schistosoma infection using random amplified polymorphic DNA analysis (RAPDs). Rev Inst Med Trop S Paulo. 1999;41(5):291-295.

29. Qvarnstrom Y, Visvesvara GS, Sriram R, da Silva AJ. Multiplex realtime PCR assay for simultaneous detection of Acanthamoeba spp., Balamuthia mandrillaris, and Naegleria fowleri. J Clin Microbiol. 2006; 44(10):3589-3595.

30. Al-Herrawy AZ. In Vitro Cultivation of Agents of Amoebic Meningoencephalitis Isolated from Water and Sewage [doctoral thesis]. Alexandria: Alexandria University; 1992.

31. Hamadto HH, Aufy SM, el-Hayawan IA, Saleh MH, Nagaty IM. Study of free living amoebae in Egypt. J Egypt Soc Parasitol. 1993;23(3): 631-637.

32. Hilali M, Ashmawy K, Samaha H, Draz AA, Abu El-Wafa SA, Salem A. Preliminary studies on amoebic pathogens isolated from water and sewage with respect to Naegleria and Acanthamoeba. J Egypt Vet Med Ass. 1994;54:215-224.

33. Al-Herrawy A, Bahgat M, Mohammed A, Ashour A, Hikal W. MorphoPhysiological and Biochemical Criteria of Acanthamoeba spp. Isolated from the Egyptian Aquatic Environment. Iran J Parasitol. 2013;8(2): 302-312.

34. Kilvington S, Gray T, Dart J, et al. Acanthamoeba keratitis: the role of domestic tap water contamination in the United Kingdom. Invest Ophthalmol Vis Sci. 2004;45(1):165-169.
35. De Jonckheere JF. Origin and evolution of the worldwide distributed pathogenic amoeboflagellate Naegleria fowleri. Infect Genet Evol. 2011;11(7):1520-1528.

36. Kao PM, Tung MC, Hsu BM, et al. Quantitative detection and identification of Naegleria spp. in various environmental water samples using realtime quantitative PCR assay. Parasitol Res. 2013;112(4):1467-1474.

37. Kao PM, Chou MY, Tao CW, et al. Diversity and seasonal impact of Acanthamoeba species in a subtropical rivershed. Biomed Res Int. 2013;2013:405794.

38. John DT, Howard MJ. Seasonal distribution of pathogenic free-living amebae in Oklahoma waters. Parasitol Res. 1995;81(3):193-201.

39. Garcia A, Goñi P, Cieloszyk J, et al. Identification of free-living amoebae and amoeba-associated bacteria from reservoirs and water treatment plants by molecular techniques. Environ Sci Technol. 2013;47(7): 3132-3140.

40. Kao PM, Hsu BM, Hsu TK, et al. Seasonal distribution of potentially pathogenic Acanthamoeba species from drinking water reservoirs in Taiwan. Environ Sci Pollut Res Int. 2015;22(5):3766-3773.

41. Kyle DE, Noblet GP. Seasonal distribution of thermotolerant free-living amoebae. I. Willard's Pond. J Protozool. 1986;33(3):422-434.

42. Kyle DE, Noblet GP. Seasonal distribution of thermotolerant free-living amoebae. II. Lake Issaqueena. J Protozool. 1987;34(1):10-15.

43. Pasricha G, Sharma S, Garg P, Aggarwal RK. Use of 18S rRNA genebased PCR assay for diagnosis of Acanthamoeba keratitis in non-contact lens wearers in India. J Clin Microbiol. 2003;41(7):3206-3211.
Reports in Parasitology

\section{Publish your work in this journal}

Reports in Parasitology is international, peer-reviewed, open access journal publishing original research, reports, reviews and commentaries on all areas of parasitology. The manuscript management system is completely online and includes a very quick and fair peer-review

\section{Dovepress}

system. Visit http://www.dovepress.com/testimonials.php to read real quotes from published authors. 